\title{
Using sulfur and oxygen isotopes to analyze the source of sulfate associated with the Eastern Route of the South-to-North Water Diversion Project in China
}

\author{
Wenlong Xie ${ }^{1}$, Weijun Tian ${ }^{1}$, Jianren Zhou ${ }^{2}$, JIng Zhao ${ }^{1}$, Liang Wang ${ }^{1}$, Zhaoyang Du ${ }^{1}$, \\ Kaili Qiao ${ }^{1}$, Meile $\mathrm{Chu}^{1}$, and Tiantian Song ${ }^{1}$ \\ ${ }^{1}$ Ocean University of China \\ ${ }^{2}$ Environmental Protection Department of Shandong Province
}

September 17, 2020

\begin{abstract}
Since the Eastern Route of the South-to-North Water Diversion Project (SNWD-ERP) officially began operation, it was found that the concentrations of sulfate rapidly increased after water transfer from Jiangsu Province to Shandong Province, especially in Nansi Lake (NSL). The direct and original sources of sulfate in NSL and its surrounding inflowing rivers were investigated by analyzing the hydrochemical properties of the water bodies and sulfur and oxygen isotope compositions of dissolved sulfate during nondiversion and diversion water periods. During the diversion water period, the largest direct source of high SO42concentrations in NSL was evaporite dissolution, accounting for $52.18 \%$ of the total contribution. In contrast, during the nondiversion water period, the maximum contribution of SO42- came from inflowing river inputs. To ensure the safety of the water supply of the SNWD-ERP, some measures must be taken to decrease the sulfate inputs from inflowing rivers, such as formulating strict discharge standards to reduce the direct discharge of sewage into the inflowing rivers around NSL.
\end{abstract}

Using sulfur and oxygen isotopes to analyze the source of sulfate associated with the Eastern Route of the South-to-North Water Diversion Project in China

Running Head : Sulfate sources in the South-to-North Water Diversion Project in China.

Abstract:Since the Eastern Route of the South-to-North Water Diversion Project (SNWD-ERP) officially began operation, it was found that the concentrations of sulfate rapidly increased after water transfer from Jiangsu Province to Shandong Province, especially in Nansi Lake (NSL). The direct and original sources of sulfate in NSL and its surrounding inflowing rivers were investigated by analyzing the hydrochemical properties of the water bodies and sulfur and oxygen isotope compositions of dissolved sulfate during nondiversion and diversion water periods. During the diversion water period, the largest direct source of high $\mathrm{SO}_{4}{ }^{2-}$ concentrations in NSL was evaporite dissolution, accounting for $52.18 \%$ of the total contribution. In contrast, during the nondiversion water period, the maximum contribution of $\mathrm{SO}_{4}{ }^{2-}$ came from inflowing river inputs. To ensure the safety of the water supply of the SNWD-ERP, some measures must be taken to decrease the sulfate inputs from inflowing rivers, such as formulating strict discharge standards to reduce the direct discharge of sewage into the inflowing rivers around NSL.

Keywords:Nansi Lake; Sulfate; $\delta^{34} \mathrm{~S}_{\mathrm{SO} 4} ; \delta^{18} \mathrm{O}_{\mathrm{SO} 4}$; Diversion water period

\section{Introduction}

China is a country with water shortages, and the per capita water resources of China are below the global average (Du, Fan, Liu, Park, Tang, 2019;Liu \& Yang, 2012; State Council, 2012) . The most 
obvious feature is the disequilibrium in water resources between the north and the south, which is largely due to the uneven spatial distribution of precipitation, and the northern region is generally less water-rich than the South China region (Bian, Yan \& Xu, 2014; Peng, Zhang, Yin \& Wang, 2018; Wei, Yang, Abbaspur, Monsavi \& Gnauck, 2010; Xinchun et al., 2017; Yang \& Zehnder, 2016; Zhao, Zuo \& Zillante, 2017). The socioeconomic development of the northern region is greatly limited by the lack of water resources (Li, Xiong, Zhang, Wang \& Wang, 2016; Zhao et al., 2017; Zhang \& Anadon, 2014) . Therefore, in 2002, the Chinese government launched the South-to-North Water Diversion Project (SNDP) to solve the problem of water shortages in the northern region (He, Hipel \& Kilgour, 2014) . The SNDP is divided into three routes, including the Western Route Project, the Middle Route Project and the Eastern Route Project.

The Eastern Route Project (SNDP-ERP) is an integral part of the South-to-North Water Diversion Project in China. The project spans the Yangtze River basin, Yellow River basin, Huai River basin and Hai River basin, and the total channel distance of water diversion is approximately 1,466.24 kilometers (Zhuang et al., 2019 ). The SNWD- ERP diverts water from the lower reaches of the Yangtze River to Jiangsu, Shandong and Hebei Provinces, and to Tianjin municipality with a complex hydraulic system of interconnected lakes, rivers and canals (Fig. 1 ). Interconnected lakes, such as Nansi Lake, are thus used as storage reservoirs and water channels. The SNWD-ERP has officially been operational for six years, starting in May 2012; it runs during the dry season and stops during the wet season, which greatly reduces the water-shortage pressure along the water transfer line. However, it is difficult to ensure long-term water quality due to the complex hydraulic system (Gu, Shao \& Jiang, 2012; Li, Li \& Zhang, 2011; Zhuang et al., 2019) . Long-term monitoring indicated that the sulfate concentrations increased rapidly after water transfer from Jiangsu Province to Shandong Province and reached $400 \mathrm{mg} / \mathrm{L}$ in Nansi Lake.

Sulfur is not only quite common in the Earth's crust but is also a common and important biological element (Schlesinger, 2005; Valiente et al., 2017 ). Sulfur acts as an electron acceptor and electron donor in many redox reactions; therefore, the sulfur cycle plays an important role in biogeochemical processes (Clark \& Fritz, 1997; Hoefs, 2015; Feng; Li et al., 2011; Ono, Sim \& Bosak, 2014; Rock \& Mayer, 2009; Spence \& Telmer, 2005). Although sulfate is nontoxic, if sulfate concentrations are too high, water quality declines, and high concentrations may even cause diarrhea in humans (Killingsworth \& Bao, 2015; Nakano et al., 2005 ). Sulfate is a ubiquitous component in surface waters. The origins of sulfate in surface water are divided into two groups: a) natural sources, that is, form evaporite dissolution, atmospheric deposition, and sulfide oxidation, and b) anthropogenic emissions, that is, form chemical fertilizer use, urban sewage and industrial mine wastewater discharge ( Brenot, Carignan, France-Lanord \& Benoit, 2007; Calmels, Gaillardet, Brenot \& France-Lanord, 2007; Cao, Wu, Zhou, Sun \& Han, 2018; Killingsworth \& Bao, 2015; Krouse \& Mayer, 2000; Otero, Soler \& Cannals, 2008; Sun, Kobayashi, Strosnider \& Wu, 2017; Yang, Telmer \& Veizer, 1996; Yoon et al., 2008 ).

The sulfur isotope compositions of sulfate are different if the sulfate sources are different (Brenot et al., 2007; Ingri, Torssander, Andersson, Morth \& Kusakabem, 1997; Krouse \& Mayer, 2000; Morth, Torssander, Kusakabe \& Hultberg, 1999; Schiff, Spoelstra, Semkin \& Jeffries, 2005; Tuttle, Breit \& Cozzarelli, 2009; Yoon et al., 2008; Yuan \& Mayer, 2012 ). Therefore, stable sulfur isotopes have been used in the past several decades to track the sources of dissolved sulfates (Hosono, Delinom, Nakano, Kagabu \& Shimada, 2011; Killingsworth \& Bao, 2015; Kim, Yun, Yoon \& Mayer, 2019; Rivas, Pozo \& Paz, 2014; Valiente et al., 2017; Yoon et al., 2008; Zhou et al., 2016; ). However, it is difficult to study the original sources of dissolved sulfates in lakes; e.g., the dissolved sulfates from atmospheric precipitation and sulfide have the same isotope signature (Mayer, Shanley, Bailey \& Mitchell, 2010; Yang et al., 2010 ; Tuttle et al., 2009). As a result, the $\delta^{34} \mathrm{~S}$ value range may overlap (the $\delta^{34} \mathrm{~S}$ values from both of the above sulfate sources are low). The sulfur isotope composition is affected by biological reduction and negatively correlated with the sulfate concentrations (low concentrations and high isotope values), which may coincide with the sulfur isotope values of the sulfates formed by evaporite dissolution(Krouse \& Mayer, 2000; Stam, Mason, Pallue \& Cappellen, 2010; Young, Cadieux, Peng, White \& Pratt, 2018 ). The abovementioned phenomena make analyses of the sources of dissolved 
sulfates complicated.

The oxygen isotope composition of newly formed sulfates depends on many different factors in natural water bodies, and it is possible to characterize sulfate sources by coupling the isotopes of sulfur and oxygen (Balci, Shanks, Mayer \& Mandernack, 2007; Karim \& Vezier, 2000 ). Therefore, studies have begun to confirm the sulfate sources of in rivers, glaciers, groundwater, wetlands and the atmosphere by using a dual isotope approach (Cao et al., 2018; Guo et al., 2019; Killingsworth \& Bao, 2015; Li, Gan, Zhou \& Liu, 2015; Young et al., 2018; Zhou et al., 2016 ). However, there are few studies of the sulfate sources associated with artificial water transfer.

The aims of this study is to trace the sources of dissolved sulfate after water enters Shandong Province using a dual isotope approach. Nansi Lake was chosen as the targeted study area because it has the highest sulfate concentrations in Shandong Province. The geological characteristics, hydrochemical types and sulfur and oxygen isotope compositions of sulfate in Nansi Lake, the surrounding rivers, and underground water during the nondiversion and diversion water periods (Jul. 2018, and Jan. 2019) were investigated and analyzed.

\section{Materials and methods}

\subsection{Study area}

Nansi Lake (NSL) is an important storage hub of the SNWD-ERP. This lake is located in western Shandong Province (WSD), (34 $27^{\prime}$ to 35deg20' $\mathrm{N}$ and 116deg34' to 117deg21' E). NSL consists of four sublakes: the Nanyang, Dushan, Zhaoyang and Weishan sublakes, extending from north to south. NSL is the largest lake in North China, with a water area of $1,266 \mathrm{~km}^{2}$ and 53 inflowing rivers. NSL is situated in a warm temperate zone, and the climate is a subhumid continental monsoon climate with $700 \mathrm{~mm}$ of annual precipitation. The evaporites in WSD are dominated by rock salts and gypsum salts, and gypsum salts (gypsum mines) are mainly distributed in the southwestern portion of WSD (Qi, 2010 ).

\subsection{Sampling}

Around NSL and the surrounding rivers, two samplings campaigns were conducted during nondiversion and diversion water periods (Jul. 2018, and Jan. 2019). According to the previous monitoring data for sulfates in NSL (obtained from the Shandong South-to-North Water Diversion Project Construction Administration), 17 samples were collected during the diversion water period, including samples from 11 rivers entering NSL, one from groundwater, one from a transfer channel and four from the center of the lake; the samples were named Sample 1-17 (S1-S17). Moreover, 11 samples were collected during the nondiversion water period (Fig. 2 ). The water samples were filtered through a $0.45-\mu \mathrm{m}$ Millipore membrane of cellulose acetate and were hermetically stored in high-density polyethylene (HDPE) bottles for chemical and isotope analysis. In addition, a gypsum sample was collected from a large gypsum mine near NSL.

\subsection{Analytical methods}

\subsubsection{Chemical analysis}

A portable water quality analyzer (HACH, HQ-40d) was used to measure the temperature $(\mathrm{T}), \mathrm{pH}$, and electrical conductivity (EC) values at the sampling sites. Additionally, the alkalinity $\left(\mathrm{HCO}_{3}{ }^{-}\right.$metering) of the samples was measured by Gran titration with $0.025 \mathrm{~N} \mathrm{HCl} \mathrm{(aq.)} \mathrm{in} \mathrm{the} \mathrm{field.} \mathrm{The} \mathrm{samples} \mathrm{for} \mathrm{measuring}$ cations were acidified to $\mathrm{pH}<2$ with ultrapure $\mathrm{HNO}_{3}$. Approximately $200 \mathrm{~mL}$ of water was subsampled from each water sample to measure the anion and cation concentrations of $\mathrm{Cl}^{-}, \mathrm{SO}_{4}{ }^{2-}, \mathrm{NO}_{3}{ }^{-}, \mathrm{Na}^{+}, \mathrm{K}^{+}, \mathrm{Ca}^{2+}$, and $\mathrm{Mg}^{2+}$ by ion chromatography (ICS-3000, DIONEX). The precision of the anion and cation concentrations were better than $5 \mathrm{mg} / \mathrm{L}$.

\subsubsection{Isotopes analysis}

Approximately $2 \mathrm{~L}$ of water was subsampled in a beaker and acidified to $\mathrm{pH}<2$ with distilled $6 \mathrm{M} \mathrm{HCl}$ to remove $\mathrm{HCO}_{3}{ }^{-}$or $\mathrm{CO}_{3}{ }^{2-}$, and $\mathrm{BaSO}_{4}$ was precipitated by adding $10 \% \mathrm{BaCl}_{2}$ (aq.) to the beaker and left to stand overnight. The gypsum sample was ground to a powder, which was dissolved in $10 \% \mathrm{NaCl}$ (aq.) for 24 
hours and then filtered through a $0.45-\mu \mathrm{m}$ Millipore membrane of cellulose acetate. The filtrates were acidified to $\mathrm{pH}<2$ with $25 \% \mathrm{HCl}$ (aq.), and $\mathrm{BaSO}_{4}$ was precipitated by adding excessive $10 \% \mathrm{BaCl}_{2}$ (aq.) to the beaker and left to stand overnight (Goldberg, Poulton \& Strauss, 2005; Kampschulte, Bruckschen \& Strauss, 2001 ). Then, the $\mathrm{BaSO}_{4}$ precipitated from the gypsum sample, and the water samples were both filtered and collected on a $0.45-\mu \mathrm{m}$ Millipore membrane of cellulose acetate. The precipitate was continuously flushed with ultrapure water until the $\mathrm{Cl}^{-}$concentrations could be ignored in the filtrates (tested with $\mathrm{AgNO}_{3}$ reagent). Finally, the precipitate was dried for 24 hours at 60 .

The $\mathrm{BaSO}_{4}$ from each sample was divided into two portions, and the sulfur and oxygen isotopes were measured by using a continuous flow isotope mass spectrometer (CF-IRMS, CV Instrument Corp., UK). One portion was placed in a tin cup and burned and decomposed to $\mathrm{SO}_{2}$ in an elemental analyzer (Euro EA 3000, Euro Vector S.P.A., Italy) at $1,000{ }^{\circ} \mathrm{C}$ and was then passed into IRMS (IsoPrime) by a helium gas stream to measure the value of $\delta^{34} \mathrm{~S}_{\mathrm{SO} 4}$. The other portion was wrapped tightly in a silver cup, was burned and lysed to $\mathrm{CO}$ in the same analyzer at $1,280{ }^{\circ} \mathrm{C}$; then, the product was passed into IRMS (IsoPrime) by a helium gas stream to measure the $\delta^{18} \mathrm{O}_{\mathrm{SO} 4}$ value. The resulting values of $\delta^{34} \mathrm{~S}_{\mathrm{SO} 4}$ and $\delta^{18} \mathrm{O}_{\mathrm{SO} 4}$ were compared with the Vienna Canyon Diablo Troilite (V-CDT) standard and the Vienna Standard Mean Ocean Water (V-SMOW) standard, respectively. The international sulfur standard, NBS-127, was measured as an internal standard correction. The precision of the $\delta^{34} \mathrm{~S}_{\mathrm{SO} 4}$ and $\delta^{18} \mathrm{O}_{\mathrm{SO} 4}$ analyses was estimated to be better than \pm 0.2

\section{Results}

\subsection{Hydrochemistry}

Table 1 shows the chemical data for each water sample in the nondiversion $(\mathrm{n}=11)$ and diversion water periods $(\mathrm{n}=17)$. In the nondiversion and diversion water periods, the $\mathrm{SO}_{4}{ }^{2-}$ concentrations ranged from $158 \mathrm{mg} / \mathrm{L}$ to $277.65 \mathrm{mg} / \mathrm{L}$ and from $170.49 \mathrm{mg} / \mathrm{L}$ to $631.5 \mathrm{mg} / \mathrm{L}$, respectively. The $\mathrm{SO}_{4}{ }^{2-}$ concentrations in the diver-

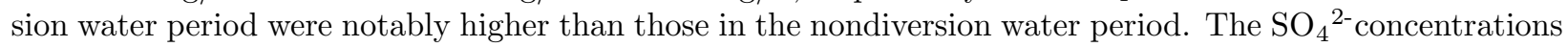
in NSL showed a gradual increasing trend from south to north in both periods, and the maximum value of $\mathrm{SO}_{4}{ }^{2-}$ was observed in the Nanyang sublake (NE). The highest concentrations of some major ions, such as $\mathrm{HCO}_{3}{ }^{-}, \mathrm{Cl}^{-}, \mathrm{Na}^{+}$and $\mathrm{Mg}^{2+}$, were observed in the Nanyang sublake (SW) ( $\mathrm{HCO}_{3}{ }^{-}$up to 245.51 and 215.28 $\mathrm{mg} / \mathrm{L}, \mathrm{Cl}^{-}$up to 155.51 and $138.02 \mathrm{mg} / \mathrm{L}, \mathrm{Na}^{+}$up to 226.59 and $170.33 \mathrm{mg} / \mathrm{L}$ and $\mathrm{Mg}^{2+}$ up to 7.77 and $42.85 \mathrm{mg} / \mathrm{L}$ in the two periods). The $\mathrm{SO}_{4}{ }^{2-}$ concentrations and concentrations of other major ions, except for $\mathrm{Na}^{+}$and $\mathrm{K}^{+}$, in the Nanyang sublake (SW) were similar to those in the Nanyang sublake (NE). The $\mathrm{pH}$ and EC values in the Nanyang sublake (SW) were greatest in NSL during the nondiversion water period and reached 8.5 and $1,388 \mu \mathrm{s} / \mathrm{cm}$, respectively. The concentrations of $\mathrm{SO}_{4}{ }^{2-}$ and other ions in the Dushan and Zhaoyang sublakes were lower than those in the Nanyang sublake, except for $\mathrm{NO}_{3}{ }^{-}$and $\mathrm{Ca}^{2+}$.

The $\mathrm{SO}_{4}{ }^{2-}$ concentrations in the main inflowing rivers around NSL ranged from $149.00 \mathrm{mg} / \mathrm{L}$ to $685.49 \mathrm{mg} / \mathrm{L}$ during the nondiversion water period. The maximum $\mathrm{SO}_{4}{ }^{2-}$ concentrations appeared in the Chengguo River, the main river entering the Zhaoyang sublake. The Sihe River, Old Wanfu River, Guangfu River, Zhushui River, Zhuzhaoxin River and Old Canal are important inflowing rivers around the Nanyang sublake. The average $\mathrm{SO}_{4}{ }^{2-}$ concentration in these rivers was approximately $319.34 \mathrm{mg} / \mathrm{L}$, with maximum concentrations being observed in the Zhuzhaoxin River (up to $590.65 \mathrm{mg} / \mathrm{L}$ ). Similar to the findings in the nondiversion water period, the $\mathrm{SO}_{4}{ }^{2-}$ concentrations in the inflowing rivers around NSL ranged from $142.06 \mathrm{mg} / \mathrm{L}$ to $671.32 \mathrm{mg} / \mathrm{L}$ during the diversion water period, and the maximum value appeared in the Zhuzhaoxin River, a major inflowing river of the Nanyang sublake (NE). The $\mathrm{Na}^{+}$content in the Zhuzhaoxin River was also maximum value among those for all the inflowing rivers, reaching $357.04 \mathrm{mg} / \mathrm{L}$, and the $\mathrm{Cl}^{-}$content was slightly lower than that in the Old Wanfu River. The Old Wanfu River not only displayed the maximum $\mathrm{Cl}^{-}$ value $(320.66 \mathrm{mg} / \mathrm{L})$ but also the highest $\mathrm{EC}(1,967 \mu \mathrm{s} / \mathrm{cm})$ and $\mathrm{HCO}_{3}{ }^{-}$values $(451.18 \mathrm{mg} / \mathrm{L})$ among all river samples. Additionally, there was little difference in the $\mathrm{SO}_{4}{ }^{2-}$ concentrations between the Zhuzhaoxin River and the Old Wanfu River. The Old Wanfu River is a main inflowing river of the Nanyang sublake (SW). The $\mathrm{SO}_{4}{ }^{2-}$ concentration in the Old Canal was $559.69 \mathrm{mg} / \mathrm{L}$ and was slightly lower than that in the Zhuzhaoxin River. The proportions of $\mathrm{SO}_{4}{ }^{2-}$ and other major ions in the river samples around NSL exhibited trends 
similar to those in NSL.

Compared to those in the rivers, the $\mathrm{SO}_{4}{ }^{2-}$ concentrations in groundwater were lower during the nondiversion water period, whereas $\mathrm{HCO}_{3}{ }^{-}$contents were as high as $506.47 \mathrm{mg} / \mathrm{L}$ and the $\mathrm{Ca}^{2+}$ content reached a maximum value of $143.81 \mathrm{mg} / \mathrm{L}$. In contrast to the trends in the nondiversion water period, the $\mathrm{SO}_{4}{ }^{2-}$ concentrations in groundwater clearly increased, and other major ion contents, such as $\mathrm{HCO}_{3}{ }^{-}, \mathrm{Cl}^{-}, \mathrm{Na}^{+}, \mathrm{Mg}^{2+}$ and $\mathrm{Ca}^{2+}$, displayed marked increases during the diversion water period.

These hydrochemical data can be used to determine the water type. The main water types of NSL during the nondiversion and diversion water periods were $\mathrm{Na}^{+}-\mathrm{SO}_{4}{ }^{2-}-\mathrm{Cl}^{-}$and $\mathrm{Na}^{+}-\mathrm{SO}_{4}{ }^{2-}-\mathrm{HCO}_{3}{ }^{-}$, respectively (Fig. 3 ). Similar to NSL, the water types of the main inflowing rivers were $\mathrm{Na}^{+}-\mathrm{SO}_{4}{ }^{2-}-\mathrm{Cl}^{-}$and $\mathrm{Na}^{+}-\mathrm{SO}_{4}{ }^{2-}-\mathrm{HCO}_{3}{ }^{-}$, respectively. The water type in NSL and the surrounding rivers was similar to Gonghe geothermal water (Liu, Guo, Zhang, Wang \& Wang, 2017), where the ions mainly came from gypsum dissolution; therefore, the ions in NSL and the surrounding rivers might have the same ion sources. However, the water types in groundwater was $\mathrm{Ca}^{2+}-\mathrm{SO}_{4}{ }^{2-}-\mathrm{Cl}^{-}$during both the nondiversion and diversion water periods. This finding indicates that the impact of groundwater inputs on NSL is low.

\subsection{Isotopic data}

The dual isotopic data for lake, river and underground water samples are shown in Table 1. In the nondiversion and diversion water periods, the $\delta^{34} \mathrm{~S}_{\mathrm{SO} 4}$ values in the lake samples ranged from $9.5(\mathrm{SW})$ ) and from 11.78sublake) respectively, with average values of 11.78 respectively. The fluctuation ranges of $\delta^{34} \mathrm{~S}_{\mathrm{SO} 4}$ in the nondiversion and diversion water periods showed little variation. The $\delta^{34} \mathrm{~S}_{\mathrm{SO} 4}$ values in river samples in the nondiversion and diversion water periods ranged from -0.07Chengguo River) to 22.15the Sihe River) to 14.55 mean values of 10.92 the lake samples, the fluctuation ranges of $\delta^{34} \mathrm{~S}_{\mathrm{SO} 4}$ values in the river samples were greater, and the $\delta^{34} \mathrm{~S}_{\mathrm{SO} 4}$ value range during the nondiversion water period was greater than that during the diversion water period.

The values of $\delta^{18} \mathrm{O}_{\mathrm{SO} 4}$ in lake samples ranged from 8.33(SW)) and from 8.6in the nondiversion and diversion water periods, respectively, with average values of 10.14 the values of $\delta^{18} \mathrm{O}_{\mathrm{SO} 4}$ varied from 7.59 from 6.27 the nondiversion and diversion water periods, respectively, with mean values of $9.90 \delta^{18} \mathrm{O}_{\mathrm{SO}}$ values from lake samples displayed the same pattern as the $\delta^{34} \mathrm{~S}_{\mathrm{SO} 4}$ values. However, the fluctuation ranges of $\delta^{18} \mathrm{O}_{\mathrm{SO} 4}$ values from river samples were definitely smaller than those of $\delta^{34} \mathrm{~S}_{\mathrm{SO} 4}$ values. The maximum $\delta^{18} \mathrm{O}_{\mathrm{SO} 4}$ and $\delta^{34} \mathrm{~S}_{\mathrm{SO} 4}$ values for both the lake and river samples appeared at the same location during the nondiversion and diversion water periods. The change in $\delta^{34} \mathrm{~S}_{\mathrm{SO} 4}$ values was not clear in most of the samples for different periods, except samples from the Chengguo River (Table 1 and Fig. 4(i) ), and the $\delta^{18} \mathrm{O}_{\mathrm{SO} 4}$ values in samples all approached a trend of 1:1 (Table 1 and Fig. 4(j) ), except for the Sihe River. It can be assumed that the $\mathrm{SO}_{4}{ }^{2-}$ source in these two rivers had changed. In addition, the $\delta^{34} \mathrm{~S}_{\mathrm{SO} 4}$ and $\delta^{18} \mathrm{O}_{\mathrm{SO} 4}$ values from the gypsum collected around NSL were 15.70

\section{Discussion}

\subsection{Sulfate characteristics during the two sampling periods}

The $\mathrm{SO}_{4}{ }^{2-}$ concentrations were significantly high in NSL, and they could have been influenced by seasonality. Usually, in the wet season, large amounts of precipitation dilute surface water, resulting in a decrease in some chemicals, whereas in the dry season with little rainfall, evaporation can cause salinity variations, such as for $\mathrm{SO}_{4}{ }^{2-}$ and $\mathrm{Cl}^{-}$. The maximum $\mathrm{SO}_{4}{ }^{2-}$ concentrations in NSL in the diversion water period (dry season) were more than three times greater than those in the nondiversion water period (wet season). The contents of the other major ions and $\mathrm{pH}$ values in the diversion water period were higher than those during the nondiversion water period (Fig. 4 ).

The $\mathrm{SO}_{4}{ }^{2-}$ concentrations in NSL were positively correlated with those in the surrounding rivers. As shown in Table 1, the $\mathrm{SO}_{4}{ }^{2-}$ concentrations in the sublakes surrounded by some inflowing rivers with high $\mathrm{SO}_{4}{ }^{2-}$ contents were significantly higher than those in other areas. During the diversion water period, the $\mathrm{SO}_{4}{ }^{2-}$ contents were highest in the Zhuzhaoxin River and in the Old Canal, the main rivers inflowing into the 
Nanyang sublake (NE), and accordingly, the $\mathrm{SO}_{4}{ }^{2-}$ concentrations in the Nanyang sublake (NE) were considerably higher than those in the other sublakes (Table $\mathbf{1}$ and Fig. $\mathbf{2}$ ). This result suggested that the inflowing rivers might be major contributors to the increase in $\mathrm{SO}_{4}{ }^{2-}$ concentrations in NSL. Similarly, other major ions in the sublakes of the NSL presented the same patterns as in the inflowing rivers. This result was in agreement with the results of a previous study (Valiente et al., 2017 ), suggesting that in surface waters, $\mathrm{SO}_{4}{ }^{2-}$ concentrations can be affected by external inputs (streams), beyond precipitation and evaporation processes.

The concentrations of $\mathrm{SO}_{4}{ }^{2-}$ and $\mathrm{Cl}^{-}$in surface waters can change due to rainfall and evaporation, but the relative ratios for the two sampling periods would change little (Drzewicki, Trojanowska-Olichwer, Jedrysek \& Halas, 2017 ). However, as shown in Fig. 4(e), the $\mathrm{SO}_{4}{ }^{2-} / \mathrm{Cl}^{-}$ratio values in the diversion water period were generally higher than those in the nondiversion water period, implying that there could be other factors responsible for the increase in the $\mathrm{SO}_{4}{ }^{2-}$ concentrations in lakes and rivers in addition to decreased rainfall in the diversion water period, such as sewage inputs.

\subsection{Sources of sulfate in the NSL}

According to the above discussion of hydrochemical and isotopic characteristics in NSL and the main inflowing rivers, the potential sources of sulfate in NSL were mainly related to atmospheric precipitation, river inputs, and evaporite dissolution. Atmospheric precipitation is an important potential source of sulfate in surface water ( $\mathbf{L i}$ et al., 2011 ). According to Krouse and Mayer (2000), the values of $\delta^{34} \mathrm{~S}_{\mathrm{SO} 4}$ and $\delta^{18} \mathrm{O}_{\mathrm{SO} 4}$ from atmospheric deposition ranged from -3measured values of $\delta^{34} \mathrm{~S}_{\mathrm{SO} 4}$ and $\delta^{18} \mathrm{O}_{\mathrm{SO} 4}$ from the lake samples fell outside of these ranges. It was also noted that there was little acid precipitation in the study area (Yu et al., 2017 ), indicating that atmospheric deposition was not the main source of the sulfate present in NSL.

As seen in Fig. $5, \mathrm{SO}_{4}{ }^{2-}$ in NSL mainly came from sewage and evaporate dissolution, and sewage was only carried into the lake through the inflowing rivers around NSL, as a policy prohibits direct sewage discharge into the lake. Therefore, the direct sources of $\mathrm{SO}_{4}{ }^{2-}$ in NSL were the evaporite dissolution and river inputs. In addition, the isotopic signatures were changed by microbial sulfate reduction in the anaerobic environment of water bodies (Young et al., 2018 ), resulting in low $\mathrm{SO}_{4}{ }^{2-}$ concentrations but high $\delta^{34} \mathrm{~S}$ values; hence, information on sulfate sources might be obscured by microbial sulfate reducers (Valiente et al., 2017 ). However, there was no significant negative correlation between the $\mathrm{SO}_{4}{ }^{2-}$ contents and ${ }^{34} \mathrm{~S}_{\mathrm{SO} 4}$ values during the nondiversion and diversion water periods (Fig. 6 ), and NSL is difficult to form an anaerobic environment due to long-term high dissolved oxygen (Tian, Pei, Hu \& Xie, 2012 ). Therefore, the effect of microbial sulfate reducers on the sulfur isotope composition can be overlooked in NSL.

\subsection{Contributions from different sulfate sources}

After sulfate dissolves in water, it is difficult to change its isotopic composition

(microbial reduction has little effect on sulfate in natural water); therefore, the source information is retained ( Li et al., 2011; Zhou et al., 2016) used the characteristics of the isotopic composition in natural water and successfully determined that the sulfate in the Jialing River in the rainy season is mainly derived from sulfide oxidation with a $56 \%$ contribution ratio, and in the dry season, the sulfate is mainly derived from domestic and industrial wastewater with a $49 \%$ contribution ratio. Therefore, in this paper, stable isotopes were also used to calculate the contribution ratios from each source of sulfate in NSL.

To accurately calculate the contribution rates, according to the geographic position

of each main $\mathrm{SO}_{4}{ }^{2-}$ source, NSL was divided into different areas. In the nondiversion water period, the $\mathrm{SO}_{4}{ }^{2-}$ contents in the Nanyang sublake and its inflowing rivers were high, and the concentrations in other sublakes and their inflowing rivers were low, except in the Chengguo River. Additionally, low $\mathrm{SO}_{4}{ }^{2-}$ contents have little effect on the environmental and water quality in natural waters. Therefore, the Nanyang sublake, as the key research area of NSL, was divided into different areas to calculate the contribution rates of each main $\mathrm{SO}_{4}{ }^{2-}$ source. Unlike in the nondiversion water period, NSL was divided into different areas in the 
diversion water period, because of the environmental influence of high $\mathrm{SO}_{4}{ }^{2-}$ contents in each sublake and the inflowing rivers during the diversion water period could not be ignored.

\subsubsection{Nondiversion water period}

Fig. 3 shows that there were significant differences in the chemical types of water

in the Old Canal and in the Nanyang sublake and that the $\mathrm{SO}_{4}{ }^{2-}$ concentrations in the Old Canal were lower than those in the Nanyang sublake. Therefore, the Old Canal was not the main source for the Nanyang sublake, and the impact of the Old Canal on sulfates in the Nanyang sublake could be ignored during the nondiversion water period.

In addition, the converging area of the Sihe River and the Nanyang sublake was the boundary of the distribution of the gypsum salts in the WSD, and there was more gypsum salts distributed in the area of southwest of the Sihe River ( $\mathbf{Q i}, \mathbf{2 0 1 0}$ ). Therefore, $\mathrm{SO}_{4}{ }^{2-}$ from evaporite dissolution was not considered as the main source of sulfate in the Nanyang sublake, except in the converging area of the Sihe River and the Nanyang sublake.

According to the spatial distribution of the adjacent main $\mathrm{SO}_{4}{ }^{2-}$ source, the Nanyang sublake was divided into three parts: NYSL-1, NYSL-2 and NYSL-3 (Fig. 7(a) ). NYSL-1 was the mixing area of the Guangfu River, the Zhushui River and the Nanyang sublake. NYSL-2 was the convergence area of the Sihe River and the Nanyang sublake. NYSL-3 was the mixing area of the Zhuzhaoxin River, the Old Wanfu River and the Nanyang sublake. We hypothesized that the $\delta^{34} \mathrm{~S}_{\mathrm{SO} 4}$ values in each region reached the value observed in the Nanyang sublake during the nondiversion water period. The $\delta^{34} \mathrm{~S}_{\mathrm{SO} 4}$ values were measured to the northeast and southwest of the Nanyang sublake due to the complex $\mathrm{SO}_{4}{ }^{2-}$ concentration distributions in the Nanyang sublake. In the NYSL-1 and NYSL-2 regions, the $\delta^{34} \mathrm{~S}_{\mathrm{SO} 4}$ value was $12.50 \delta^{34} \mathrm{~S}_{\mathrm{SO} 4}$ value was 13.35 (Table 1 ) .

The $\mathrm{SO}_{4}{ }^{2-}$ contribution rates of each main source can be calculated by the following formulas (Li et al., 2011 ):

$\delta^{34} \mathrm{~S}_{\text {lake }}=\delta^{34} \mathrm{~S}_{\mathrm{i}}{ }^{*} \mathrm{~A}+\delta^{34} \mathrm{~S}_{\mathrm{j}}{ }^{*} \mathrm{~B}(1)$

$\mathrm{A}+\mathrm{B}=100 \%(2)$

$\delta^{34} \mathrm{~S}_{\text {lake }}=\delta^{34} \mathrm{~S}_{\text {gypsum }} * \mathrm{C}+\delta^{34} \mathrm{~S}_{\mathrm{k}} * \mathrm{D}(3)$

$\mathrm{C}+\mathrm{D}=100 \%$

where $\delta^{34} \mathrm{~S}_{\text {lake }}$ is the value of $\delta^{34} \mathrm{~S}_{\mathrm{SO} 4}$ in the lake; $\delta^{34} \mathrm{~S}_{\mathrm{i}}, \delta^{34} \mathrm{~S}_{\mathrm{j}}$ and $\delta^{34} \mathrm{~S}_{\mathrm{k}}$ are the values of ${ }^{34} \mathrm{~S}_{\mathrm{SO} 4}$ from different inflowing river inputs; and $\delta^{34} \mathrm{~S}_{\text {gypsum }}$ is the value of $\delta^{34} \mathrm{~S}_{\mathrm{SO} 4}$ in gypsum $(15.70 \mathrm{C}$ and $\mathrm{D}$ are the contribution rates. Eq. (1) and Eq.(2) were used for NYSL-1 and NYSL-3, and Eq. (3) and Eq. (4) were used for NYSL-2.

All the calculated contribution rates are summarized in Table $\mathbf{2}$, and the maximum contribution of $\mathrm{SO}_{4}{ }^{2-}$ in the Nanyang sublake came from the Old Wanfu River input and was as high as $32.56 \%$, followed by the contribution of evaporite dissolution $(25.60 \%)$. Therefore, the inflowing river inputs were the main sulfate source in the Nanyang sublake in the nondiversion water period.

\subsubsection{Diversion water period}

With the increased high $\mathrm{SO}_{4}{ }^{2-}$ concentrations to high levels in inflowing rivers, the distributions of the $\mathrm{SO}_{4}{ }^{2-}$ content in NSL during the diversion water period was complicated. According to the $\mathrm{SO}_{4}{ }^{2-}$ distributions, NSL was divided into three major areas, named as the Zhaoyang and Weishan sublake areas (ZWSL), the Dushan sublake area (DSSL) and the Nanyang sublake area (NYSL) (Fig. 7(b) ). To accurately calculate the contribution rates from each source, ZWSL, DSSL and NYSL were further divided into three subregions, two subregions and four subregions, respectively, in accordance 
with the locations of adjacent major sulfate sources. The first three subregions were the convergence areas of the Hanzhuang Canal and the Weishan sublake, the Panlong River and the Weishan sublake, and the Chengguo River and the Zhaoyang sublake. The fourth and fifth subregions were the lake mixing areas of the Baima River and Dongyu River with the Dushan sublake, respectively. The sixth subregion was the mixing area of the Sihe River and the Nanyang sublake. The final three subregions were the mixing areas of the Old Wanfu River and the Wanfu River, the Zhuzhaoxin River and the Zhushui River, and the Old Canal and the Guangfu River. It was hypothesized that the $\delta^{34} \mathrm{~S}_{\mathrm{SO} 4}$ value in each subregion reached the value in each corresponding sublake during the diversion water period.

To calculate the $\mathrm{SO}_{4}{ }^{2-}$ contribution rates, Eq. (3) and Eq. (4) were used for the first six subregions, and Eq. (1) and Eq. (2) were used for the latter three subregions. A $\delta^{34} \mathrm{~S}_{\mathrm{SO} 4}$ value of 11.78 used for the first, second and third subregions, and 14.63the $\delta^{34} \mathrm{~S}_{\mathrm{SO} 4}$ value for DSSL for the fourth and fifth subregions. Additionally, $12.86 \delta^{34} \mathrm{~S}_{\mathrm{SO} 4}$ value of the lake in the seventh subregion. The remaining subregions used $14.10 \delta^{34} \mathrm{~S}_{\mathrm{SO} 4}$ value of the lake (Table 1 and Fig. 7(b) ). The calculated contribution rate of each river in NYSL to the respective subregions was divided by 12, and contribution rate of each river in DSSL and ZWSL were divided by 6 and 9 respective. The contribution rates of each source to the NSL was obtained. The results are presented in Table 3 .

According to Eq. (3) and Eq. (4), the total $\mathrm{SO}_{4}{ }^{2-}$ contribution rates of evaporite dissolution to NSL was $52.18 \%$, with the maximum contribution rate occurred during the diversion water period. The $\mathrm{SO}_{4}{ }^{2-}$ source from inflowing river inputs cannot be neglected, especially for the Zhuzhaoxin River, Old Canal, and Wanfu River (total contribution of 22.76\%). Moreover, these three rivers all flowed into the Nanyang sublake, where the $\mathrm{SO}_{4}{ }^{2-}$ contributions from inputs were largely higher than those from evaporite dissolution.

In contrast to trends in the NYSL, the $\mathrm{SO}_{4}{ }^{2-}$ sources for the DSSL and ZWSL both came mainly from evaporite dissolution, and the contribution rates of inflowing rivers provided lower amounts of sulfate. In addition, the Hanzhuang Canal is a channel for artificial water transfer from Jiangsu Province to Shandong Province during the diversion water period. As shown in Table $\mathbf{3}$, the contribution rate from artificial water transfer to NSL was low compared with that from evaporite dissolution and with the contribution of other inflowing rivers. Notably, sulfate from diversion water was not the main source in NSL.

By comparing the contributions of $\mathrm{SO}_{4}{ }^{2-}$ sources in NSL in the nondiversion and diversion water periods, mainly concentrating on the Nanyang sublake, it was evident that the contributions had significant differences. For example, the Wanfu River was not the main $\mathrm{SO}_{4}{ }^{2-}$ source for the Nanyang sublake in the nondiversion water period, but it provided the maximum contribution during the diversion water period. Similar changes also occurred in the Old Canal. In addition, the $\mathrm{SO}_{4}{ }^{2-}$ contribution rate of the Zhuzhaoxin River increased greatly from the nondiversion to diversion water periods. However, the $\mathrm{SO}_{4}{ }^{2-}$ contribution of the Old Wanfu River decreased dramatically. The $\mathrm{SO}_{4}{ }^{2-}$ contribution from evaporite dissolution to the Nanyang sublake changed little between the nondiversion and diversion water periods.

\subsection{Sources of sulfate in the inflowing rivers}

The main sources of sulfate in rivers and water transfer included atmospheric deposition, evaporite dissolution, the oxidation of sulfides, and human inputs (Brenot et al., 2007; Cao et al., 2018; Killingsworth \& Bao, 2015; Sun et al., 2017; Yoon et al., 2008 ). The sulfate from human inputs into the river system came mainly from domestic sewage. Therefore, the $\mathrm{SO}_{4}{ }^{2-}$ sources in the rivers around NSL were divided into four types: a) atmospheric deposition, b) evaporite dissolution, c) sulfide oxidation, and d) sewage.

From Fig. 5, the values of $\delta^{34} \mathrm{~S}_{\mathrm{SO} 4}$ and $\delta^{18} \mathrm{O}_{\mathrm{SO} 4}$ from samples such as those from the Old Canal, Guangfu River, Zhuzhaoxin River, Wanfu River and the Old Wanfu River in both periods were associated with sources of evaporite dissolution. Specifically, the Zhuzhaoxin River, the Old Canal and the Wanfu River, all entered the Nanyang sublake with high $\mathrm{SO}_{4}{ }^{2-}$ contributions. Although the $\mathrm{SO}_{4}{ }^{2-}$ from evaporite dissolution was less than $30 \%$ in the NYSL according to the calculated contribution rates (for two periods), the rivers entering the Nanyang sublake had high concentrations and contribution rates of $\mathrm{SO}_{4}{ }^{2-}$, which came from evaporite dissolution. Therefore, it is reasonable to assume that the $\delta^{34} \mathrm{~S}_{\mathrm{SO} 4}$ and $\delta^{18} \mathrm{O}_{\mathrm{SO} 4}$ values of the Nanyang 
sublake plot in the evaporite dissolution area in Fig. $\mathbf{5}$.

The $\delta^{34} \mathrm{~S}_{\mathrm{SO} 4}$ and $\delta^{18} \mathrm{O}_{\mathrm{SO} 4}$ values of the Panlong River, Chengguo River, Baima River and Dongyu River were in the range of the sewage sources; therefore, the $\mathrm{SO}_{4}{ }^{2-}$ sources of these rivers were mainly from artificial inputs during the diversion water period. These rivers are large rivers with wider watershed areas and are important water resources for the cities in each watershed. Domestic sewage from large cities, such as Jining and Zaozhuang, might be received by these rivers. In addition, the Zhushui River plots in the overlapping area between evaporite dissolution and sewage, as shown in Fig. 5 . The $\mathrm{SO}_{4}{ }^{2-}$ source of the Zhushui River during the nondiversion water period mainly plots in the area of evaporite dissolution. During the diversion water period, sewage became one of the primary sources, and the values of $\delta^{34} \mathrm{~S}_{\mathrm{SO} 4}$ and $\delta^{18} \mathrm{O}_{\mathrm{SO} 4}$ in the Zhushui River were influenced, resulting in shifts in the values of $\delta^{34} \mathrm{~S}_{\mathrm{SO} 4}$ and $\delta^{18} \mathrm{O}_{\mathrm{SO} 4}$ to values that plot in the sewage area.

The $\delta^{34} \mathrm{~S}_{\mathrm{SO} 4}$ and $\delta^{18} \mathrm{O}_{\mathrm{SO} 4}$ values in the Hanzhuang Canal were in the range of atmospheric deposition and plotted near the sewage area, which could have been the result of a mixture of sewage and atmospheric deposition sources. The $\mathrm{SO}_{4}{ }^{2-}$ source of the Chengguo River in the nondiversion water period was atmospheric deposition, but the source in the diversion water period involved both sewage and atmospheric deposition. By comparing the $\mathrm{SO}_{4}{ }^{2-}$ contents of the Chengguo River in the nondiversion and diversion water periods, sewage had a greater contribution rate in the diversion water period. However, in the nondiversion water period, due to sufficient rainfall and the abundant coal resources in the Chengguo River Basin, sulfur dioxide from coal combustion might have eventually transformed into sulfate and then entered the Chengguo River through precipitation.

\section{Conclusions}

In the present study, to clarify the problem of increasing sulfate levels in the SNWD-ERP, the sources of sulfate in NSL, an important storage hub of the SNWD-ERP, were traced through hydrochemical research and by sulfur and oxygen isotope analysis. We obtained documented hydrochemical evidence of sulfate changes in the two periods, and the changes were linked to seasonal overturn, evaporite dissolution and inputs from the rivers that flow into NSL.

During the nondiversion water period (wet season), the $\mathrm{SO}_{4}{ }^{2-}$ concentrations were significantly lower in NSL, except for that in the Nanyang sublake, than in the diversion period. The maximum $\mathrm{SO}_{4}{ }^{2-}$ contribution in the Nanyang sublake came from the inputs of inflowing rivers, especially that from the Old Wanfu River, providing up to $32.56 \%$ of the total contribution. In addition, the $\mathrm{SO}_{4}{ }^{2-}$ contribution from evaporite dissolution accounted for $25.60 \%$ of the total level. In the diversion water period (dry season), the largest source of the high $\mathrm{SO}_{4}{ }^{2-}$ concentrations in NSL came from evaporite dissolution, accounting for $52.18 \%$ of the total contribution. However, the $\mathrm{SO}_{4}{ }^{2-}$ proportion from inflowing river inputs into NSL could not be ignored, especially for the inputs from the Zhuzhaoxin River, Old Canal and Wanfu River, with $\mathrm{SO}_{4}{ }^{2-}$ contributions of $8.10 \%, 7.54 \%$ and $7.12 \%$, respectively. Notably, in the NYSL, the $\mathrm{SO}_{4}{ }^{2-}$ contributions of these rivers were higher than those from evaporite dissolution.

Thus, to guarantee satisfactory diversion water quality, it is essential to initiate treatment methods to decrease the $\mathrm{SO}_{4}{ }^{2-}$ content, such as by using activated carbon or charcoal adsorption, before water is diverted from NSL to transfer pipelines. In addition, the $\mathrm{SO}_{4}{ }^{2-}$ contributions from sewage in inflowing rivers are a major sulfate source, such especially for the Chengguo and Panlong Rivers. Therefore, it is necessary to formulate strict discharge standards to reduce the direct discharge of sewage into the rivers that flow into NSL.

\section{References}

Balci, N., W.C. Shanks, B. Mayer, \& K.W. Mandernack. 2007. Oxygen and sulfur isotope systematics of sulfate produced by bacterial and abiotic oxidation of pyrite. Geoch. Cosmch. Acta. 71 (15), pp. 3796-3811.

Bian, Y., S. Yan \& H. Xu. 2014. Efficiency evaluation for regional urban water use and wastewater decontamination systems in China: A DEA approach. Resources, Conservation and Recycling 83,pp. 15-23. 
Brenot, A., J. Carignan, C. France-Lanord \& M. Benoît. 2007. Geological and land use control on $\delta 34$ S and $\delta 18 \mathrm{O}$ of river dissolved sulfate: The Moselle river basin, France. Chem. Geol. 244, pp. 25-41.

Calmels, D., J. Gaillardet, A. Brenot \& C. France-Lanord. 2007. Sustained sulfide oxidation by physical erosion processes in the Mackenzie River basin: Climatic perspectives. Geol. 35, pp. 1003-1006.

Cao, X., P. Wu, S. Zhou, J. Sun \& Z. Han. 2018. Tracing the origin and geochemical processes of dissolved sulphate in a karst-dominated wetland catchment using stable isotope indicators. J. Hydrol. 562, pp. 210222.

Clark, I.D.\& P. Fritz. 1997. Environmental Isotopes in Hydrogeology. Lewis Publishers, New York.

Du, W., Y. Fan, X. Liu, S.C. Park \& X. Tang. 2019. A game-based production operation model for water resource management: An analysis of the South-to-North Water Transfer Project in China. J. Clean. Prod. 228, pp. 1482-1493.

Drzewicki, W., A. Trojanowska-Olichwer, M.O. Jedrysek, \& S. Hałas. 2017. The variability of $\delta 34$ S and sulfur speciation in sediments of the Sulejów dam reservoir (Central Poland). Geochem. 77, pp. 147-157.

Feng, J., F. Chen \& H. Hu. 2017. Isotopic study of the source and cycle of sulfur in the Yamdrok Tso basin, Southern Tibet, China. Appl. Geochem. 85, pp. 61-72.

Goldberg, T., S. Poulton \& H. Strauss. 2005. Sulphur and oxygen isotope signatures of late Neoproterozoic to early Cambrian sulphate, Yangtze Platform, China: Diagenetic constraints and seawater evolution. Precambrian Res. 137, pp. 223-241.

Gu, W., D. Shao \& Y. Jiang. 2012. Risk Evaluation of Water Shortage in Source Area of Middle Route Project for South-to-North Water Transfer in China. Water Resour. Manag. 26, pp. 3479-3493.

Guo, Z., Q. Guo, S. Chen, B. Zhu, Y. Zhang, J. Yu \& Z. Guo. 2019. Study on pollution behavior and sulfate formation during the typical haze event in Nanjing with water soluble inorganic ions and sulfur isotopes. Atmos. Res. 217, pp. 198-207.

He, S., K.W. Hipel \& D.M. Kilgour. 2014. Water Diversion Conflicts in China: A Hierarchical Perspective. Water Resour. Manag. 28, pp. 1823-1837.

Hoefs, J. 2015. Stable Isotope Geochemistry, seventh ed. Springer, Heidelberg.

Hosono, T., R. Delinom, T. Nakano, M. Kagabu \& J. Shimada. 2011. Evolution model of $834 \mathrm{~S}$ and $818 \mathrm{O}$ in dissolved sulfate in volcanic fan aquifers from recharge to coastal zone and through the Jakarta urban area, Indonesia. Sci. Total Environ. 409, pp. 2541-2554.

Ingri, J., P. Torssander, P.S. Andersson, C.M. Morth \& M. Kusakabem. 1997. Hydrogeochemistry of sulfur isotopes in the Kalix River catchment, northern Sweden. Appl. Geochem. 12(4), pp. 483-496.

Kampschulte, A., P. Bruckschen \& H.Strauss. 2001. The sulphur isotopic composition of trace sulphates in Carboniferous brachiopods: implications for coeval seawater, correlation with other geochemical cycles and isotope stratigraphy. Chem. Geol. 175, pp. 165-189.

Karim A. \& J. Vezier. 2000. Weathering processes in the Indus Basin: implications from riverine carbon, sulfur, oxygen and strontium isotopes. Chem. Geol. 170, pp. 153-177.

Killingsworth, B.A. \& H. Bao. 2015. Significant Human Impact on the Flux and $834 \mathrm{~S}$ of Sulfate from the Largest River in North America. Environ. Sci. Technol. 49, pp. 4851-4860.

Kim, D., S. Yun, S. Yoon \& B. Mayer. 2019. Signature of oxygen and sulfur isotopes of sulfate in ground and surface water reflecting enhanced sulfide oxidation in mine areas. Appl. Geochem. 100, pp. 143-151.

Krouse, H.R. \& B. Mayer. 2000. Sulfur and oxygen isotopes in sulfate. In: Cook, P.G., Herczeg, A.L. (Eds.), Environmental Trecers in Subsurface Hydrology. Kluwer, Boston, pp. 195-231 (Chapter 7). 
Li, S., J. Li \& Q. Zhang. 2011. Water quality assessment in the rivers along the water conveyance system of the middle route of the south to North water transfer project (China) using multivariate statistical techniques and receptor modeling. J. Hazard. Mater. 195, pp. 306-317.

Li, S., C. Liu, S. Patra, F. Wang, B. Wang \& F. Yue. 2011. Using a dual isotopic approach to trace sources and mixing of sulphate in Changjiang Estuary, China. Appl. Geochem. 26, pp. S210-S213.

Li, X., Y. Gan, A. Zhou \& Y. Liu. 2015. Relationship between water discharge and sulfate sources of the Yangtze River inferred from seasonal variations of sulfur and oxygen isotopic compositions. J. Geochem. Explor. 153, pp. 30-39.

Li, Y., W. Xiong, W. Zhang, C. Wang \& P. Wang. 2016. Life cycle assessment of water supply alternatives in water-receiving areas of the South-to-North Water Diversion Project in China. Water Res. 89, pp. 9-19.

Liu, J. \& W. Yang. 2012. Water sustainability for China and beyond. Science 337, pp. 649-650.

Liu, M., Q. Guo, C. Zhang, M. Zhu \& J. Li. 2017. Sulfur Isotope Geochemistry Indicating the Source of Dissolved Sulfate in Gonghe Geothermal Waters, Northwestern China. Procedia Earth and Planetary Science 17, pp. 157-160.

Mayer, B., J.B. Shanley, S.W. Bailey \& M.J. Mitchell. 2010. Identifying sources of stream water sulfate after a summer drought in the Sleepers River watershed ( Vermont,USA) using hydrological,chemical,and isotopic techniques. Appl. Geochem. 25(5), pp. 747-754.

Mo“ rth C.M., P. Torssander, M. Kusakabe \& H. Hultberg. 1999. Sulfur isotope values in a forested catchment over four years: evidence for oxidation and reduction processes. Biogechem. 44, pp. 51-71.

Nakano, T., I. Tayasu, E. Wada, A. Igeta, F. Hyodo \& Y. Miura. 2005. Sulfur and strontium isotope geochemistry of tributary rivers of Lake Biwa: implications for human impact on the decadal change of lake water quality. Sci. Total Environ. 345, pp. 1-12.

Otero, N., A. Soler \& À.Canals. 2008. Controls of $\delta 34 \mathrm{~S}$ and $\delta 18 \mathrm{O}$ in dissolved sulphate: Learning from a detailed survey in the Llobregat River (Spain). Appl. Geochem. 23, pp. 1166-1185.

Ono, S., M.S. Sim \& T. Bosak. 2014. Predictive isotope model connects microbes in culture and nature. Proc. Natl. Acad. Sci. U.S.A. 111, pp. 18102-18103.

Peng, Z., L. Zhang, J. Yin \& H. Wang. 2018. Study of impact factors of willingness to pay regarding water reserve of South-to-North Water Diversion Project in Beijing based on Bayesian network model. J. Clean Prod. 184, pp. 569-578.

Qi, L.L. 2010. Study on main factors of tertiary salt mineral sediment in Shandong Province. Shandong University of Science and Technology, Shandong, China, (in Chinese).

Rivas, T., S. Pozo \& M. Paz. 2014. Sulphur and oxygen isotope analysis to identify sources of sulphur in gypsum-rich black crusts developed on granites. Sci. Total Environ. pp. 482-483, 137-147.

Rock, L. \& B. Mayer. 2009. Identifying the influence of geology, land use, and anthropogenic activities on riverine sulfate on a watershed scale by combining hydrometric, chemical and isotopic approaches. Chem. Geol. 262, pp. 121-130.

Schiff, S.L., J. Spoelstra, R.G. Semkin \& D.S. Jeffries. 2005. Drought induced pulses of $\mathrm{SO}_{4}{ }^{2-}$ from a Canadian shield wetland: use of $\delta^{34} \mathrm{~S}$ and $\delta^{18} \mathrm{O}$ in $\mathrm{SO}_{4}{ }^{2-}$ to determinesources of sulfur. Appl. Geochem. 20 (4), pp. 691-700.

Schlesinger, W.H., 2005. Biogeochemistry. vol. 8 Gulf Professional Publishing.

Spence, J. \& K. Telmer. 2005. The role of sulfur in chemical weathering and atmospheric CO2 fluxes: Evidence from major ions, $813 \mathrm{CDIC}$, and $834 \mathrm{SSO} 4$ in rivers of the Canadian Cordillera. Geochim. Cosmochim. Ac. 69 , pp. 5441-5458. 
State Council, 2012. Opinions on the Implementation of the Most Stringent. Water Resources Management, China.

Stam, M.C., P.R.D. Mason, C. Pallud \& P. Van Cappellen. 2010. Sulfate reducing activity and sulfur isotope fractionation by natural microbial communities in sediments of a hypersaline soda lake (Mono Lake, California). Chem. Geol. 278(1-2), pp. 23-30.

Sun, J., T. Kobayashi, W.H.J. Strosnider \& P.Wu. 2017. Stable sulfur and oxygen isotopes as geochemical tracers of sulfate in karst waters. J. Hydrol. 551, pp. 245-252.

Tian, C., H. Pei, W. Hu \& J. Xie. 2012. Variation of cyanobacteria with different environmental conditions in Nansi Lake, China. J. Environ. Sci-China 24, pp. 1394-1402.

Tuttle, M.L.W., G.N. Breit \& I.M. Cozzarelli. 2009. Processes affecting $\delta 34$ S and $\delta 180$ values of dissolved sulfate in alluvium along the Canadian River, central Oklahoma, USA. Chem. Geol. 265, pp. 455-467.

Valiente, N., R. Carrey, N. Otero, M.A. Gutiérrez-Villanueva, A. Soler \& D. Sanz. 2017. Tracing sulfate recycling in the hypersaline Pétrola Lake (SE Spain): A combined isotopic and microbiological approach. Chem. Geol. 473, pp. 74-89.

Wei, S., H. Yang, K. Abbaspour, J. Mousavi \& A. Gnauck. 2010. Game theory based models to analyze water conflicts in the Middle Route of the South-to-North Water Transfer Project in China. Water Res. 44, pp. 2499-2516.

Xinchun, C., W. Mengyang, G. Xiangping, Z. Yalian, G. Yan, W. Nan \& W. Weiguang. 2017. Assessing water scarcity in agricultural production system based on the generalized water resources and water footprint framework. Sci. Total Environ. 609, pp. 587-597.

Yang, C., K. Telmer \& J. Veizer. 1996. Chemical dynamics of the "St. Lawrence" riverine system: dDH2O, d18OH2O, d13CDIC, d34Ssulfate, and dissolved 87Sr/86Sr. Geochim. Cosmochim. Acta. 60, pp. 851-866.

Yang, H. \& A. Zehnder. 2016. China's Regional Water Scarcity and Implications for Grain Supply and Trade. Environment and Planning A: Economy and Space 33, pp.79-95.

Yang, Y.C, Z.L. Shen, D.G. Wen, G.C. Hou, H.Q. She \& Z.H. Zhao. 2010. Distribution of $\delta 34$ S and $\delta 180$ in SO42-in groundwater from the Ordos cretaceous ground-water basin and geological implications. Acta. Geologica. Sinica: English Edition. 84(2), pp. 432-440.

Yoon, J., Y. Huh, I. Lee, S. Moon, H. Noh \& J. Qin. 2008. Weathering Processes in the Min Jiang: ${ }^{87} \mathrm{Sr} /{ }^{86} \mathrm{Sr}$, $\delta^{34} \mathrm{~S}_{\mathrm{SO} 4}$, and $\delta^{18} \mathrm{O}_{\mathrm{SO} 4}$. Aquat. Geochem. 14, pp. 147-170.

Young, S.A., S.B. Cadieux, Y. Peng, J.R. White \& L.M. Pratt. 2018. Seasonal changes in sulfur biogeochemistry of a dilute, dimictic Arctic lake: Implications for paired sulfur isotope records from ancient oceans. Chem. Geol. 495, pp. 118-130.

Yu, H., N. He, Q. Wang, J. Zhu, Y. Gao \& Y. Zhang. 2017. Development of atmospheric acid deposition in China from the 1990s to the 2010s. Environ. Pollut. 231, pp. 182-190.

Yuan, F. \& B. Mayer. 2012. Chemical and isotopic evaluation of sulfur sources and cycling in the Pecos River, New Mexico, USA. Chem. Geol. 291, pp. 13-22.

Zhang, C. \& L.D. Anadon. 2014. A multi-regional input-output analysis of domestic virtual water trade and provincial water footprint in China. Ecol. Econ. 100, pp. 159-172.

Zhao, Z., J. Zuo \& G. Zillante. 2017. Transformation of water resource management: a case study of the South-to-North Water Diversion project. J. Clean Prod. 163, pp. 136-145.

Zhou, J., Q. Zhang, F. Kang, Y. Zhang, L. Yuan, D. Wei \& S. Lin. 2016. Using multi-isotopes $\left({ }^{34}\right.$ S, $\left.{ }^{18} \mathrm{O},{ }^{2} \mathrm{H}\right)$ to track local contamination of the groundwater from Hongshan-Zhaili abandoned coal mine, Zibo city, Shandong province. Int. Biodeter Biodegr.128, pp. 48-55. 
Zhuang, W., S.C. Ying, A.L. Frie, Q. Wang, J. Song \& Y. Liu. 2019. Distribution, pollution status, and source apportionment of trace metals in lake sediments under the influence of the South-to-North Water Transfer Project, China. Sci. Total Environ. 671, pp. 108-118.

\section{Hosted file}

Tables.docx available at https://authorea.com/users/359866/articles/481631-using-sulfur-andoxygen-isotopes-to-analyze-the-source-of-sulfate-associated-with-the-eastern-route-ofthe-south-to-north-water-diversion-project-in-china

\section{Hosted file}

Figures.docx available at https://authorea.com/users/359866/articles/481631-using-sulfurand-oxygen-isotopes-to-analyze-the-source-of-sulfate-associated-with-the-eastern-routeof-the-south-to-north-water-diversion-project-in-china 